\title{
Os tempos de Mallarmé nas antologias brasileiras de poesia traduzida
}

\author{
The times of Mallarmé in the brazilian \\ anthologies of translated poetry
}

Álvaro Faleiros ${ }^{\star}$

\section{RESUMO}

O intuito deste trabalho é refletir sobre diferentes tempos da recepção da poesia de Mallarmé no Brasil a partir do lugar que ele ocupa nas antologias de poesia traduzida.

Palavras-chave: Mallarmé; tradução no Brasil; antologias.

\section{ABSTRACT}

The purpose of this work is to reflect about different times of Mallarmés poetry reception in Brazil, as from the place it occupies in poetry anthologies.

Keywords: Mallarmé, translation in Brazil, anthologies.

\footnotetext{
* Universidade de São Paulo.
} 


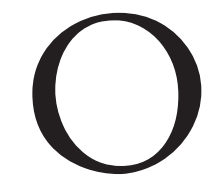
bservar o lugar que Mallarmé ocupa nas diferentes antologias de poesia francesa traduzida no Brasil é um dos modos possíveis de se identificar diferentes tempos de sua recepção entre nós. Nesse sentido, é notável a sua ausência nas primeiras antologias. Cláudio Veiga, em seu estudo sobre a tradução de poesia francesa no Brasil ${ }^{1}$, faz um levantamento dessas antologias e ressalta que, no século XIX, não há antologias de poesia francesa reunindo diferentes autores. O que se encontra são apenas as coletâneas em homenagem aos poetas românticos Victor Hugo e Alphonse de Lamartine².

Segundo Veiga, a primeira antologia brasileira de poeta franceses foi publicada na Bahia em 1917. Trata-se de Musa Francesa, organizada por Álvaro Reis, na qual todos textos estão só em português e há uma espécie de cronologia na apresentação dos poetas. Depois de abrir sua antologia com um poema do canadense Louis Fréchette dedicado à França, Álvaro Reis apresenta uma série

1 “A tradução de poesia francesa no Brasil". Antologia da Poesia Francesa, 2 ed., Rio de janeiro, Record, 1999, p. 435-462.

2 Trata-se das obras Lamartineanas (1869) e Hugonianas (1885), ambas recolhas de diversos tradutores, publicadas quando da morte dos dois poetas franceses. 
Faleiros, A.

Os tempos

de Mallarmé

nas antologias

brasileiras de poesia traduzida

de traduções de Lamartine, Arvers, Hugo, Musset, Gauthier, Leconte de Lisle, Sully Prudhome, Banville, Hérédia (o mais traduzido, com 13 poemas), além de três poemas de Baudelaire. A maioria dos poetas é, contudo, pouco conhecida; dentre eles estão, por exemplo, Soulary, Ackermann, Bouillet, Pailleron, Armand Silvestre, Mendes, Haraucourt, Richepin, Lebesgue, Vaucaire, Mikhael etc. Trata-se, sobretudo, de poetas parnasianos e, apesar de haver um importante diálogo de Mallarmé com o Parnaso, não há nenhuma referência a ele no livro.

O mesmo silêncio prossegue na segunda antologia a que Veiga se refere. Em Antologia de Tradutores, organizada por Olegario Marianno e publicada em 1932 pela editora Guanabara, há traduções de diversos tradutores, dentre os quais Olavo Bilac, Manuel Bandeira, Martins Fontes, João Ribeiro, Humberto de Campos, Guimarães Passos, Felix Pacheco e Alphonsus de Guimarães. Há traduções de poetas os mais variados, desde Sully-Prudhomme, Heine, Assunción Silva, Stechetti e Verlaine até Corneille, Furster, Victor Hugo, Goethe, Catullo, Rostand, Tibullo... Em meio a tantos poetas, segue o silêncio em torno de Mallarmé.

Como indicado em estudo anterior ${ }^{3}$, até os anos 1930, encontramos apenas três traduções e poucas referências a Mallarmé no Brasil - "Tristesse d'été", por Escragnolle Dória, publicada com o título de "Tristeza Estival" na revista carioca Rua do Ouvidor, de 11 de maio de 1901; "L’Azur”, por Batista Cepelos, publicado em seu livro de poemas Vaidades, em 1908; e "Apparition", traduzido por Alphonsus de Guimaraens, incluído na edição de 1938 de seu livro póstumo Pastoral aos crentes do amor e da morte. Assim, a ausência de Mallarmé nas duas grandes antologias do período e a tradução de apenas três poemas de Mallarmé nas condições acima descritas ilustram bem a afirmação de Julio de Castañon Guimarães de que "parte do simbolismo brasileiro se desenvolveu independentemente do conhecimento da obra de Mallarmé". Outro fato importante que se depreende é a escolha dos textos: são poemas do jovem Mallarmé, anteriores a seus textos mais herméticos. O poema "Appariton" data de 1863, "L’Azur" e "Tristesse d'été" datam de 1864.

\section{Primeiro tempo: Poetas de França de Guilherme de Almeida}

Na publicação, em 1936, da antologia Poetas de França, de Guilherme de Almeida, ocorre a primeira inclusão de Mallarmé numa antologia, com os poemas "Brise Marine" e "Apparition", este já traduzido por Alphosus de Guimarães. O pioneirismo do trabalho de Guilherme de Almeida não se deve apenas à escolha de Mallarmé. Sua antologia contempla poetas desde François Villon até Paul Éluard, passando por Ronsard e Du Bellay, Claudel e Valéry.

Revista Letras,

3 FALEIROS, Á. Três mallarmés: traduções brasileiras. Aletria, v. 22, 2012, p.18.

4 GUIMARÃES, J. C. "Presença de Mallarmé no Brasil". Reescritas e Esboços. Rio de Janeiro: Topbooks, 2010, p.15.

Curitiba, UFPR, n. 95 143-163, jan./jun. 2017. ISSN 2236-0999 (versão eletrônica) 
Diferentemente das antologias anteriores, Guilherme de Almeida produz um grande apanhado histórico que visa, de certo modo, a trazer para o leitor cinco século de poesia francesa. Sua escolha não se deve apenas a uma afinidade, mas parece pautada por uma concepção de história literária. Como lembra Daniel Padilha Pacheco da Costa:

\begin{abstract}
Fundador da disciplina da "História da Literatura", Gustave Lanson (1857-1934) elegeu François Villon o primeiro poeta moderno francês. Ocupando uma posição privilegiada na história da literatura francesa, Villon não passou despercebido à crítica no Brasil. A História da Literatura Ocidental (1959) de Otto Maria Carpeaux (1900-1978) dedica um estudo monográfico a Villon que, como na História da Literatura Francesa de Gustave Lanson, é considerado o nascimento do lirismo moderno ${ }^{5}$.
\end{abstract}

Em Poetas de França é também publicada a primeira tradução brasileira de Villon; esta obra é o primeiro panorama histórico da poesia francesa entre nós. É também a primeira vez que temos, no Brasil, a publicação de poemas acompanhados de originais. Essa outra maneira de se pensar a tradução ${ }^{6}$ é ainda uma nova forma de organizar uma antologia, em que está em jogo a relação entre tradução, edição e antologia. André Lefevere ${ }^{7}$ identifica cinco principais formas de reescritura, que são: a tradução, a historiografia, a antologização, a 146 crítica e a edição. Em Poetas de França, nota-se justamente o cruzamento dessas distintas formas de reescrita, pois Guilherme de Almeida muda o modo de se editar ao produzir uma antologia bilíngue e repensa o próprio lugar da crítica ao se preocupar em fazer um prefácio no qual discute sua concepção de tradução. Além disso, ele decide introduzir novos poetas, historicizando a própria noção de poesia francesa, afastando-se tanto da homenagem romântica como da emulação parnasiana.

Nesse contexto, pode-se dizer que a inclusão de Mallarmé faz parte de um projeto mais amplo de construir uma espécie de história da poesia lírica francesa. Nesse projeto, Mallarmé não chega a ser central, e os dois poemas ali traduzidos não são aqueles textos que farão dele uma das mais importantes referências para a poesia do século XX. Com efeito, os poemas que Guilherme de Almeida traduz são ainda os poemas do jovem Mallarmé e, nesse sentido, sua

5 Daniel Padilha Pacheco da Costa, "Villon retraduzido", Cadernos de Literatura em Tradução, n.13, 2012, p.39.

6 No que concerne à importância de Guilherme de Almeida para o desenvolvimento de uma nova concepção de tradução no Brasil cf. FALEIROS, A. "Três mallarmés: traduções brasileiras". Aletria, v. 22, 2012; FALEIROS, Á. "A tradução de poesia no Brasil: a invenção de uma tradição". In: WEINHARDT, M.; SIMON, L. C.; RODRIGUEZ, B. M.; OLIVEIRA, S.; BUENO, L.; CARDOZO, M. M. (Org.). Ética e estética nos estudos literários. Curitiba: UFPR, 2013, p. 27-50. 7 LEFEVERE, A. Tradução, reescrita e manipulação da fama literária. Bauru: Edusc, 2007. p.17. 
Faleiros, A.

Os tempos

de Mallarmé

nas antologias

brasileiras de poesia traduzida

escolha não difere daquela de seus antecessores. Será preciso esperar a década seguinte até que se façam as primeiras alusões à modernidade de Mallarmé. Em 1942, Manuel Bandeira profere na Academia Brasileira de Letras sua conferência "O Centenário de Stéphane Mallarmé", na qual se refere à concepção orquestral da poesia mallarmeana e, no ano seguinte, Otto Maria Carpeaux, em "Situação de Mallarmée", faz uma primeira apresentação de Un coup de dés no Brasil. É Carpeaux também o primeiro a apontar para o fato de Mallarmé ter se tornado o poeta do século XX.

\section{Intervalo}

Os acontecimentos em torno do centenário de Mallarmé não tiveram ecos na grande antologia de poesia francesa que marca o final dos anos 1940. Em 1950, é publicada no Rio de Janeiro, pela gráfica Tupi, a Antologia de poetas franceses do séc. $X V$ ao séc. $X X$, organizada por Raimundo Magalhães Junior, provavelmente a melhor síntese de toda uma concepção de tradução de poesia anterior a Guilherme de Almeida. No livro, como diz o próprio autor na contra-capa, são elencadas "101 figuras representativas da poesia da França e da Bélgica através dos seus tradutores brasileiros e portugueses”. Apresentados em ordem alfabética, sem acompanhamento dos textos originais, cada um dos poetas é representado por um número bastante variável de poemas. Se a grande maioria deles está presente com um ou dois poemas - dentre os quais Apollinaire, Banville, Cocteau, Corneille, Éluard, Laforgue, Nerval, Racine, Prévert, Valéry, Verhaeren, Villon - há outros cujo conjunto de textos é mais representativo, destacando-se Baudelaire (25 poemas), Victor Hugo (22 poemas), Hérédia (20 poemas) e Verlaine (18 poemas). Os três são seguidos por um segundo grupo formado por La Fontaine e Sully-Prudhomme (12 poemas cada), Leconte de Lisle e Musset (11 poemas cada), Gautier (10 poemas), Albert Samain (09 poemas) e Lamartine (08 poemas), seguidos de perto por François Copée (07 poemas), Edmond Haraucourt e Edmond Rostand (06 poemas cada), Henri de Regnier e Jean Richepin (05 poemas cada). Se com 04 poemas há apenas Jean Rameau e André Verdet, a lista dos poetas com 03 poemas inclui Cendrars, Chénier, Dumas Filho, Florian, Francis James, Maeterlick, Moréas, Rimbaud, Rollinat, Voltaire e o próprio Mallarmé, justamente com as traduções de "Azur" de Batista Cepellos, "Aparição" de Alphonsus de Guimaraens e "Brisa Marinha" de Guilherme de Almeida, já comentadas anteriormente.

A lista acima resume bastante bem a recepção da poesia francesa no período. Se autores hoje pouco conhecidos como Albert Samain e Edmond Haraucourt ganham destaque, isso se deve sobretudo ao trabalho de Álvaro Reis

Revista Letras, 
e de sua Musa francesa, dedicada principalmente a poetas do final do século XIX e início do século XX. O que mais chama a atenção, contudo, é o destaque dado a Baudelaire, Hugo, Hérédia e Verlaine, em detrimento de poetas que passaram a ser muito mais traduzidos na segunda metade do século XX, como Apollinaire, Corbière, Laforgue, Nerval, Prévert, Rimbaud, Valéry, Villon, além do próprio Mallarmé, cujas parcas traduções (datadas dos anos 1900-1930) serão as únicas a circular até o final dos anos 1950.

Outro dado relevante é a pequena biografia dedicada a cada um dos poetas. No caso de Mallarmé, após indicar sua data de nascimento, afirma-se que ele foi, como Baudelaire, um dos divulgadores da obra de Edgard Poe em francês e que fez uma tradução importante de $O$ corvo. A palestra proferida por Bandeira e o estudo de Carpeaux não repercutem nessa biografia, onde se destaca o Mallarmé tradutor de Poe. A essa informação soma-se apenas o fato de que foi professor de inglês e um dos precursores do movimento simbolista. $\mathrm{Na}$ biografia, o autor é citado pelas seguintes publicações: L’après-midi d’un faune (1876), Poésies complètes (1887), Vers et proses (1893), Divagations (1897); sem que seja feita qualquer menção a Igitur ou Un Coup de Dés, textos que só ganharão centralidade num segundo tempo da recepção de Mallarmé no Brasil.

\section{Segundo tempo: Mallarmé poeta de vanguarda}

A primeira importante tradução de Mallarmé nos anos 1950 encontra-se, num primeiro momento, não em um livro, mas numa coluna de jornal. Essa coluna, escrita por Mário Faustino, foi concebida com um objetivo bastante específico, o que faz dela uma espécie de antologia ${ }^{10}$. Como aponta Maria Eugênia Boaventura, de 6 de janeiro de 1957 a 24 de agosto de 1958, Mário Faustino manteve, no Suplemento Dominical do Jornal do Brasil, a coluna "Fontes e correntes da poesia contemporânea", na qual "comentou obras de escritores europeus e norte-americanos que, no seu entender, os novos poetas brasileiros deveriam observar como modelo" ${ }^{11}$. Sua coluna se inicia com um texto dedicado a Edgar Allan Poe, intitulado "O primeiro inventor", e conclui-se com "O maior verse maker", sobre Ezra Pound. Entre ambos, os textos percorrem a seguinte cronologia: Gautier, Withman, Baudelaire, Dickinson, Rimbaud, Hopkins, Lautréamont, Yeats, Verlaine, Nouveau, Cros, Hardy, Housman, Kiplin, Corbière, George, Robinson, Frost, Mallarmé, Laforgue, Darío, Saint-Pol-Roux, Régnier, Gourmont, Moréas, Maeterlinck, Lerberghe, Elskamp, Verhaeren, Masters, Sandburg, Lindsay, Claudel, Jarry, Marinetti, Palazzeschi, Soffici, Canguillo, Benetta, Apollinaire, Cendrars, Jacob, Fargue, Reverdy,

10 Todos os artigos que formam essa espécie de antologia foram reunidos por Maria Eugênia Boaventura em: FAUSTINO, M. Artesanatos de Poesia: fontes e correntes da poesia ocidental. São Paulo, Cia das Letras, 2004.

11 BOAVENTURA, Lendo com o leitor, p.19-20. 
Faleiros, A.

Os tempos

de Mallarmé

nas antologias

brasileiras de poesia traduzida
Salmon, Tzara, Schwitters, Arp, Picabia, Cravan, Ball, Ribemont-Dessaignes, Huelsenbeck, van Doesburg e Hausmann. Em cada um dos artigos, Faustino introduz em geral traduções semânticas para servir de apoio para o leitor.

No caso de Mallarmé, antes de apresentar alguns comentários seguidos das suas traduções, Faustino faz uma apresentação do poeta, dividindo sua obra em quatro fases: a) uma primeira parnasiano-simbolista (com ecos de Baudelaire e Rimbaud); b) uma segunda em que se reconcilia com o francês de Racine e antecipa Valéry; c) uma terceira em que surge o "grande Mallarmé", com seus sonetos mais audazes; d) o "derradeiro Mallarmé" de Igitur e de Un coup de dés.

Faustino não dá grande importância para as duas primeiras fases do poeta. Por exemplo, ao comentar "Apparition", já traduzido por Alphosus de Guimarães e Guilherme de Almeida, afirma:

é o mau simbolismo, nada mais do que o parnasianismo rendu flou (sem as qualidades de exatidão dos bons parnasianos, poema que tem deliciado moçoilas semicultas há lustros e mais lustros, mas que é desonesto e ridículo. Coisa que não acontece com o maravilhoso "Brise marine", simbolista mesmo, obra-prima da escola, Baudelaire elevado a certas potências, e que começa com o grande verso

La chair est triste, hélas! et j’ai lu tous les livres

Ai de mim, a carne é triste e li todos os livros!

Um pouco coup de théâtre, mas grande verso, seja como for ${ }^{12}$.

Chama atenção, no comentário de Faustino, denominado de "segunda fase" de Mallarmé, justamente a presença dos dois poemas traduzidos por Guilherme de Almeida, estabelecendo clara distinção entre eles; o que permite interpretar o trabalho de Guilherme de Almeida como uma fase de transição para a leitura moderna de Mallarmé e que tem, em Faustino, um claro ponto de inflexão. Nesse sentido, vale salientar que o primeiro poema que Faustino traduz integralmente em seu ensaio é "Prose", de 1885, que considera "a ponte entre a segunda e a terceira fase" ${ }^{\prime 3}$.

Faustino chega assim ao "terceiro Mallarmé", aquele que "seria preciso transcrever, traduzir, comentar por inteiro, verso por verso, palavra por palavra. Aí é Mallarmé ao mesmo tempo o Mestre e o Inventor" ${ }^{\prime 4}$. O primeiro poema da terceira fase efetivamente comentado é "Salut", seguido de "Au seul souci de Voyager", "Quand l'ombre menaça de la fatale loi”, "Le vierge, le vivace et le bel

12 FAUSTINO, M. Poesia não é brincadeira. Artesanatos de Poesia: fontes e correntes da poesia ocidental. São Paulo, Cia das Letras, 2004. p.162.

13 FAUSTINO, M. Idem, p.165.

14 FAUSTINO, M. Idem, p.165.
Revista Letras,

Curitiba, UFPR, n. 95 143-163, jan./jun. 2017. ISSN 2236-0999 (versão eletrônica) 
aujourd'hui" e dos "Tombeaux" dedicados a Poe, Baudelaire, Verlaine, Wagner. Em seguida, Faustino refere-se aos sonetos "Surgi de la croupe et du bond", "À la nue acablante tu" e "Mes bouquins refermés sur le nom de Paphos". Ainda que não chegue a traduzir todos integralmente, Faustino estabelece sua lista, à qual acrescenta um trecho de Igitur traduzido por José Lino Grünewald, assim como o prefácio de Un Coup de Dés, desta vez traduzido por Ercília de Azeredo.

É interessante notar a colaboração de outros tradutores justo no trecho em que apresenta aquele que chama de "Mallarmé do futuro: Un Coup de Dés e seu antecedente, Igitur" ${ }^{\prime 1}$. Talvez seja justamente para ressaltar a importância que dá a esses textos, uma vez que, ao falar da sua própria tradução, a define como "despretenciosa", "péssima e apressada"16. De todo modo, inaugura-se com a "antologia" de Faustino o grande momento da recepção e tradução de Mallarmé. A partir de então, ele não apenas passará a constar de todas as antologias de poesia francesa, como terá antologias dedicadas a sua obra. Nesse sentido, destaca-se o trabalho de toda uma geração, cujos maiores expoentes são Augusto de Campos, José Lino Grünewald, Décio Pignatari e Haroldo de Campos, sobretudo os dois primeiros, certamente os mais importantes antologistas de Mallarmé do período.

Ainda que José Lino Grünewald tenha traduzido um trecho de Igitur para Mário Faustino em 1958 e tenha publicado, na década de 1960, o poema "Brinde" no Correio da Manhã ${ }^{17}$, cabe a Augusto de Campos a organização da primeira antologia dedicada ao poeta, Mallarmargem ${ }^{18}$, reunida posteriormente no volume intitulado Mallarmé19, ao qual se somam traduções de Décio Pignatari e de Haroldo de Campos. Publicado em 1974, o livro é composto por textos críticos escritos sobre o poeta e por traduções de Haroldo de Campos (Um Lance de Dados), de Décio Pignatari (A Tarde um Fauno) e de Augusto de Campos (22 poemas curtos, na maioria sonetos). Dos quatros textos críticos que formam a parte final do livro, os dois primeiros são de autoria de Augusto de Campos, tendo sido publicados originalmente em 1955 no Diário de São Paulo. O primeiro deles, "Poesia, estrutura", versa essencialmente sobre Un Coup de Dés, e o segundo, "Poema, Ideograma" traça um paralelo entre os Caligramas de Apollinaire, a poética de Cummings, Pound, Joyce e Mallarmé, concluindo, uma vez mais a partir de Un Coup de Dés, que:

15 FAUSTINO, M. Idem, p.181.

16 FAUSTINO, M. Idem, p.181.

17 José Lino Grünewald (Poemas/ Stéphane Mallarmé, Rio de Janeiro: Nova Fronteira, 1990, p.07) afirma que o soneto "Brinde" já havia sido publicado "na atual tradução, desde a década de 1960, no Correio da Manhã.

18 Publicada em 1970 em edição de 250 exemplares pela editora Noa Noa, essa antologia nos foi até o momento inacessível, motivo pelo qual os comentários serão feitos a partir da antologia Mallarmé publicada pela Perspectiva em 1974 e reeditada repetidas vezes, na qual os poemas de Mallarmargem são retomados.

19 MALLARMÉ, S. Mallarmé. Organização, tradução e notas de Augusto de Campos, Décio Pignatari, Décio e Haroldo de Campos. São Paulo: Perspectiva, [1974] 1991. 
Faleiros, A.

Os tempos

de Mallarmé

nas antologias

brasileiras de poesia traduzida as 'subdivisões prismáticas da Ideia' de Mallarmé, o método ideogrâmico de Pound, a simultaneidade joyciana e a mímica verbal de Cummings convergem para um novo conceito de composição [...] onde noções tradicionais como início, meio, fim, silogismo, tendem a desaparecer diante a ideia poético-gestaltiana, poético-lusical, poético-ideogrâmica de ESTRUTURA ${ }^{20}$.

Essa leitura coincide com o modo como o grupo se apropria desses autores em seus manifestos escritos ao longo dos anos 195021. Curiosamente, mais de vinte anos depois, caberá a Haroldo de Campos a tradução de Un Coup de Dés. Augusto de Campos, por sua vez, será o responsável pela tradução de poemas curtos de Mallarmé. Sua seleção, retomada de Mallarmargem, e agora intitulada "Poesias (1864-1895)", é precedida de uma pequena nota, em que afirma:

A ordem dos textos segue a das Poésies de Mallarmé. Mas, sempre que possível, adicionei aos poemas as respectivas datas de composição ou publicação, baseando-me para tanto nas notas da edição Pléiade. Penso que ajudam a compreender, criticamente, a evolução formal da poesia de Mallarmé22.

Observa-se ali a presença de dois conjuntos de textos: o primeiro, formado por "Une négresse par le démon secouée", "Las de l'amer repos (fragmento final)", "Le sonneur", "L'Azur", "Brise Marine" e "Sainte", corresponde a poemas escritos entre 1863 e 1866; o segundo, formado pelos outros dezesseis poemas, cobre a fase final da obra de Mallarmé, de 1885 a 1895. Assim, ainda que apresente para o leitor o Mallarmé mais próximo de Victor Hugo e de Baudelaire, retraduzindo, por exemplo, "L’Azur" e "Brise Marine", é sobretudo sobre o Mallarmé da fase final que Augusto se debruça. Esta seguirá sendo sua contribuição até que, em 1987, abre sua antologia Linguaviagem, com o longo poema "Herodias", escrito entre 1864 e 1867 para ser um drama em versos. O fato de ser ele o poeta que abre sua antologia, onde figuram também Valéry, Keats, Yeats e Blok, mostra o caráter seminal que guarda Mallarmé.

A tradução do poema, apresentado em edição bilíngue, vem precedida de importante estudo, em que Augusto de Campos traça um paralelo entre "Herodias" e "A jovem parca" de Valéry, também traduzido na íntegra nesse volume. O Mallarmé que passa a interessar é aquele que dialoga com a poesia de Valéry, diferindo da leitura anterior, mais pautada pelo trabalho de explosão da linguagem que culminaria em Un Coup de Dés. Augusto de Campos, no

\footnotetext{
20 Idem, p.186.

21 Cf. FALEIROS, A. "Haroldo de Campos e a dobra de Mallarmé", in: Anais XI ABRALIC, 2008.

22 MALLARMÉ, S. [1974] 1991, op, cit., p.31.
}

Revista Letras,

Curitiba, UFPR, n. 95 143-163, jan./jun. 2017. ISSN 2236-0999 (versão eletrônica) 
final de seu ensaio, explica que seu interesse em traduzir poemas aparentemente tradicionais, depois de Pound, de Joyce, de Cummings - depois do próprio Un Coup de Dés - está na possibilidade de se "detectar momentos específicos de inovação em outros passos menos aparentes" ${ }^{2}$. Ele constata ainda que "a técnica do fazer poético a tal ponto se degradou, nas mais recentes gerações, que pode ser muito útil o convívio e o diálogo com as sutilezas do verso progressivo de Mallarmé e Valéry", aproximando assim a poesia concreta dessas poéticas francesas mais rigorosas por se tratar de posturas ético-poética que compartilham uma "ética de recusas" 24 . Não por acaso, Augusto de Campos cita a Carta sobre Mallarmé, em que Valéry declara: "o trabalho severo, em literatura, se manifesta e se opera por recusas”25. Essa ideia será tão cara a Augusto de Campos que, em 2006, nomeia outra antologia sua de Poesia da recusa ${ }^{26}$. Nela, uma vez mais, é dado um destaque a Mallarmé, que comparece com doze novos poemas. Nessa antologia, que começa com a tradução de dois poemas do poeta barroco alemão Quirinus Kuhlmann, logo seguido por Mallarmé, observa-se uma série de poetas russos - Alexander Blok, Anna Akhmátova, Boris Pasternak, Óssip Mandelstam, Sierguéi Iessiênin e Marina Tzvietáieva -, acompanhados de Yeats, Gertude Stein, Wallace Stevens, Hart Crane e Dylan Thomas. No primeiro parágrafo da introdução, lê-se: "Em defesa de Mallarmé, afirmou Valéry, certa vez, que o trabalho severo, em literatura se manifesta e se opera por meio de recusas; pode-se dizer que ele é medido pelo número de recusas" ${ }^{27}$. Em clara referência à antologia anterior, Augusto de Campos, desta vez, dedica uma breve introdução apenas a Mallarmée ${ }^{28}$, intitulada "A implosão poética de Mallarmé", onde afirma que:

As traduções agora apresentadas recobrem todas as fases de Mallarmé, dos versos dos primeiros anos aos da maturidade, e mostram a coerência do seu projeto, do início ao fim, estendendo progressivamente sua rebeldia até chegar ao poema intitulado paradoxalmente "Prosa", o mais enigmático e um dos mais ousados experimentos do poeta, onde se revela ao extremo o tratamento implosivo a que submete a linguagem".

\footnotetext{
23 Idem, ibidem.

24 Idem, p.41.

25 Idem, p.14.

26 CAMPOS, A. de. Poesia da recusa. São Paulo: Perspectiva, [2006] 2011. Note-se que seis desses novos poemas, dentre os quais "Prose", foram publicados em 1998 na antologia Mallarmargem 2, pela editora Noa Noa, em edição de 150 exemplares. A comparação entre as duas edições ocuparia demasiado espaço, motivo pelo qual os atemos a comentar a edição de mais ampla circulação.

27 Idem, p.15.

28 Ele faz o mesmo para a maioria dos outros poetas também. Apenas Alexander Blok, Anna Akhmátova e Boris Pasternak são tratados num mesmo texto introdutório.
} 
Faleiros, A.

Os tempos

de Mallarmé

nas antologias

brasileiras de poesia traduzida

Augusto de Campos inventa uma cronologia, colocando o poema "Prose" no final do percurso ${ }^{29}$; para Faustino, "Prose" é compreendido justamente como a passagem da segunda para a terceira fase. Se atentarmos para as datas, "Prose" é de 1884-1885 e Mallarmé segue escrevendo poemas até 1898. Aliás, em sua seleta anterior publicada em Mallarmé, a maioria dos poemas escolhidos são posteriores a "Prose". Assim, ao manipular o tempo, Augusto de Campos molda uma imagem de Mallarmé pautada pelo o que ele mesmo nomeia uma "ética de recusas".

De todo modo, é inegável o papel central que Augusto de Campos ocupa na antologização e divulgação da obra de Mallarmé. Seu trabalho, iniciado com ensaios nos anos 1950 e passando para a antologização e tradução, desde o início dos anos 1970, dá um destaque até então inédito à obra do poeta francês, que desde então recebe certa centralidade no sistema literário brasileiro. Na década seguinte, Augusto de Campos volta a colocar Mallarmé no centro de suas reflexões, dessa vez acompanhado de Paul Valéry e de um alentado ensaio que traz importantes questões éticas e estéticas para a poesia brasileira, trabalho que prossegue nas antologias seguintes - Mallarmagem 2 (1998) e Poesia da recusa (2006). A concepção de antologia aqui em jogo propõe outro tipo de crítica e edição. Como aponta Paulo Henriques Britto:

é nas diversas antologias organizadas por Augusto e Haroldo de Campos, a partir do início dos anos 60, que a imbricação entre a atividade crítica e as de poeta, tradutor e antologista se realiza de modo mais completo, e mais complexo. [...] Os tradutores que, como Augusto de Campos, sabem tirar o máximo proveito do espaço do paratexto, afirmando-se como críticos, apresentando e comentando tanto o seu processo tradutório quanto a obra e o autor sendo traduzidos, conseguem romper a barreira da invisibilidade sem turvar a fronteira entre o seu trabalho e o do autor origina ${ }^{30}$

Assim, as relações entre os poetas presentes em suas antologias não se pautam mais por um recorte geográfico, mas se vinculam a um projeto ético e poético. Não interessa para Augusto de Campos a poesia francesa e sim as posturas diante do fazer poético. Seu tempo é o de marcar posições pelo modo como recolhe, critica, comenta e traduz. E, na construção dessas relações, o tempo nas antologias é sincrônico, pois não se trata nem de aderir a uma determinada estética contemporânea, como fizeram românticos e parnasianos, nem de projetar uma diacronia, como ocorre, por exemplo, em Guilherme de Almeida.

Revista Letras,

29 O mesmo ocorre em Mallarmargem 2.

30 "O tradutor como antologista", in Marie-Helène Torres e al., op. cit., 2016, p.34.

Curitiba, UFPR, 
Postura semelhante é adotada por José Lino Grünewald. Seu trabalho envolvendo Mallarmé se inicia em torno de Igitur, de quem é, até hoje, o único tradutor entre nós. O primeiro trecho traduzido por Grünewald, como vimos, consta no artigo de Mário Faustino, de maio de 1957. Ele prossegue seu trabalho de tradução e, em 1980, publica, na Bahia, em Código n.4, o que chama de sua "forma definitiva" de Igitur ${ }^{31}$.

Assim como Mário Faustino e Augusto de Campos, Grünewald também constrói sua antologia, Transas, traições, traduções (publicada em Salvador, pela editora Código, em 1982), movido pelo desejo de definir o campo em que a poesia contemporânea deveria se mover. Propondo trajeto análogo ao de Mário Faustino $^{32}$, Grünewald dá grande destaque a Ezra Pound, a quem chama de "o maior poeta do século" 33. Em sua antologia, após apresentar traduções de "A Fênix e a Pomba" e "Threnos", de Shakespeare, Grünewald comenta e traduz seis poemas relativamente longos de Pound, seis poemas curtos de William Carlos Williams, um poema de Eliot, um de Cummings, um de Dylan Thomas, um de Ronsard, um de Baudelaire e, antes de encerrar com Apollinaire e Guido Cavalcanti, introduz um trecho de Igitur, assim como sua tradução do poema "Brinde".

A forma de sua antologia também se assemelha ao trabalho de Faustino e de Campos. Nos três, os poemas vêm acompanhados de comentários sobre sua feitura. Nos mini-ensaios que escreve, Grünewald traz desde informações sobre as condições de publicação dos originais até alguns poucos e breves comentários sobre escolhas tradutórias. No que concerne Mallarmé, Grünewald retoma duas publicações anteriores. A primeira, um trecho de Igitur, vem acompanhada de um texto de nove parágrafos ${ }^{34}$ em que, a partir de Heidegger, reflete sobre o ato de pensar em jogo nesse texto que, como indica no final, é matriz de Un Coup de Dés. A segunda, sua tradução de "Brinde", já havia sido publicada nos anos 1960 no Correio da Manhã. Nesse caso, percebe-se tanto a lembrança de que João Cabral de Melo Neto utiliza um verso "récif, solitude, étoile" como epígrafe de seu primeiro livro A Pedra do Sono, quanto o fato de os elementos ali conotados remeterem, uma vez mais, a Un Coup de Dés.

\footnotetext{
31 Infelizmente não tivemos acesso ao livro, mas retiramos essa informação de Transas, traições, traduções. Salvador: Código, 1982, antologia do próprio autor. No volume, sem numeração de página, Grünewald retoma um trecho de Igitur, no qual afirma que sua tradução foi publicada "de forma definitiva, em Código, n.4 em 1980".

32 Cabe lembrar que Mário Faustino dedica não por acaso as últimas sete semanas de sua coluna "Fontes e correntes da poesia contemporânea" a Ezra Pound, a quem chama de "o maior verse maker". Além de Pound, os únicos poetas a quem Faustino dedica mais do que uma semana de sua coluna são Apollinaire (quatro semanas) e Mallarmé (duas semanas); o que ilustra bem a importância que dá ao poeta norte-americano.

33 In: Transas, traições, traduções. Salvador: Código, 1982, s.n.

34 Ainda que não tenha sido possível consultar o original de Código n.4, pode-se supor que o texto reproduzido em Transas, traições, traduções seja o mesmo, uma vez que o texto que acompanha as duas outras re-publicações da tradução de Igitur de Grünewald - MALLARMÉ, S. Igitur. Rio de Janeiro: Nova Fronteira, 1985; e MALLARMÉ, S. Poemas. Rio de Janeiro: Nova Fronteira, 1990. - é exatamente o mesmo.
} 
Faleiros, A.

Os tempos

de Mallarmé

nas antologias

brasileiras de poesia traduzida
Revista Letras,

Curitiba, UFPR, n. 95 143-163, jan./jun. 2017. ISSN 2236-0999 (versão eletrônica)
Essa antologia, contudo, difere daquelas organizadas por Augusto de Campos, pois não vem acompanhada dos textos originais. Pode-se pensar que o fato de estar em uma revista, com restrição de número de páginas, tenha levado a essa escolha. De todo modo, não se pode esquecer seu caráter seminal, pois nela se encontram os primeiros esboços dos grandes trabalhos de tradução de poesia que serão realizados por Grünewald, dentre os quais a tradução dos Cantos de Ezra Pound, vencedora do Prêmio Jabuti, assim como a antologia Poetas franceses do século XIX e seus trabalhos envolvendo Mallarmé, um dos autores mais revisitados por Grünewald.

Com efeito, já em 1985, Igitur é relançado pela editora Nova Fronteira, em edição bilíngue e acompanhado do mesmo texto introdutório; sendo esse mesmo texto retomado uma vez mais na segunda antologia exclusivamente dedicada a Mallarmé, intitulada Poemas ${ }^{35}$. Nela, Grünewald reúne três décadas de trabalho em torno de Mallarmé. Essa antologia, contudo, difere consideravelmente das antologias precedentes dedicadas exclusivamente ao poeta. Se nas antologias dos Campos é sobretudo a poesia rimada e metrificada de Mallarmé que encontramos, em Poemas, diferentes facetas do poeta francês se dão a ver. Temos, pois, uma recolha, também bilíngue, que se inicia com a tradicional abertura, que é "Brinde", para, em seguida, apresentar um único poema de juventude, "Angústia", seguido por outros cinco poemas da terceira fase de Mallarmé, uma vez mais em destaque. A novidade é que Grünewald introduz, pela primeira vez no Brasil, poemas em prosa de Mallarmé, a saber: "O fenômeno futuro", "Lamento de outono" e "Demônio da analogia" 36 . A antologia amplia-se ainda com a retomada de Igitur, seguida de trechos de Um Lance de Dados, de O Livro e de Para um túmulo de Anatole.

O leitor passa assim a conviver com um conjunto mais amplo de textos de Mallarmé, que oferecem uma dimensão importante de seu trabalho - seus projetos inacabados. Grünewald, nos mini-ensaios que seguem acompanhando os poemas, alude ao inacabamento de Igitur, de O Livro e de Para um túmulo de Anatole. Sobre o primeiro, diz: "o próprio fato de o poeta haver deixado inacabada, não publicada, essa experiência - não ter consumado seu desligamento dela, como era sua atitude em relação a qualquer poema - ajuda, impele a instigação de enfrentar seu labirinto semântico" ${ }^{37}$. Hoje sabemos que a edição a que Grünewald teve acesso não contém todas as rasuras e hesitações do manuscrito, o que certamente produziria outros caminhos, pelo labirinto de possíveis que acarreta. Em relação a O Livro, Grünewald lida com a edição de 1957, de Jacques Scherer, o que o leva a tecer considerações mais precisas, como "o manuscrito, além de textos esparsos, vem com traços, números, cálculos etc. Demonstra a ambição de um projeto" 38 ; ou que, diante dele, sua escolha

35 MALlARMÉ, S. Poemas, Rio de Janeiro: Nova Fronteira, 1990.

36 "O demônio da analogia” já fora traduzido por Inês Oséki-Dépré e publicado, em Salvador, na revista Código de agosto de 1980.

37 MALLARMÉ, S., op. cit., 1990, p.117.

38 MALLARMÉ, S., op. cit., 1990, p.135. 
foi "traduzir três fragmentos mais elaborados, mas típicos do pensar em trânsito"39. Para um túmulo de Anatole, Grünewald consultou a edição organizada por Jean-Pierre Richard desse "esboço de um poema jamais acabado", "manuscrito [que] nunca mais foi desenvolvido" ${ }^{\text {" }}$. Essa reflexão dá ao leitor a consciência de que as imagens de uma determinada obra vão se elaborando pelos recortes que dela são feitos; perfis que se delineiam também pelos modos como se interpretam e se editam os manuscritos.

Esse conjunto de trabalhos realizados ao longo dos anos 1970 e 1980 fará com que o lugar de Mallarmé nas antologias de poesia francesa se modifique consideravelmente. A mais importante delas é Poetas franceses do século XIX, de autoria do próprio Grünewald. Na curta "nota introdutória”, ele afirma que seu trabalho não "representa um levantamento preciso e definido da poesia francesa do século passado [XIX]” e, logo depois, acrescenta:

- machadianamente - que o mundo mudou. Ou seja: há poetas que, com o tempo, perderam mais, ou mais ganharam em matéria de instigação. Infelizmente, hoje, não se podem colocar os poetas românticos franceses no mesmo plano dos alemães e, muito menos, dos ingleses. Mas, a partir de Baudelaire até o surrealismo ficou todo um mundo vibrante de significações [...] De um lado Baudelaire, Rimbaud, Verlaine [...] souberam ensinar que vício é vida [...] De outro, Mallarmé, até o seu fim na Rue de Rome, deu o seu plá. A poesia acabou ou começa com ele ${ }^{41}$.

Grünewald assume, tal como o fizera Guilherme de Almeida nos anos 1930, a posição privilegiada do antologista que não retoma o caminho antes traçado, mas que, de modo autoral, instaura um ponto de vista, inaugurando outro tempo na recepção de determinadas poéticas. Como lembra Marie-Hélène Torres, os antologistas "são também criadores autorreflexivos [...] que quebram as formas petrificadas, os clichês que bloqueiam, às vezes durante décadas, a leitura verdadeiramente viva de uma literatura" ${ }^{\star 2}$. Sua antologia é, pois, um marco. É a primeira vez que poetas como Lamartine, Hérédia e Victor Hugo perdem lugar de destaque, sendo representados com apenas um ou dois poemas, número igual ao de poetas antes ausentes ou quase, como Laforgue ou Corbière; e menos do que Lautréamont, Nerval ou Gauthier, presentes com três poemas cada. Se Baudelaire segue sobressaindo-se, com sete poemas, ele agora é seguido de perto por Verlaine (seis poemas) e por Rimbaud (cinco poemas). Nenhum

39 Idem ibidem.

40 Idem, p.141.

41 MALLARMÉ, S., op. cit., 1990, p.11.

42 TORRES, M-H. "Antologias, Coletâneas e Coleções, uma introdução". In: TORRES, M.-H.; FREITAS L.; COSTA, W. C., Literatura Traduzida: antologias, coletâneas e coleções. Fortaleza: Substânsia, 2016. p. 16. 
Faleiros, A.

Os tempos

de Mallarmé

nas antologias

brasileiras de poesia traduzida deles, contudo, iguala-se a Mallarmé, com seus oito poemas. Afinal, como afirma Grünewald em sua nota introdutória, "a poesia acabou ou começa com ele”.

O fato é que, no que concerne à tradução e recepção de Mallarmé no Brasil, outro modo de ler sua poesia começou com os trabalhos de Mário Faustino, de José Lino Grünewald e dos irmãos Campos. Assim, nas décadas de 1990 e 2000, assiste-se ao desenvolvimento de trabalhos que incorporam aspectos dessas leituras, movendo-se a partir deles, dentre as quais ocupam papel de relevo as antologias organizadas por Júlio Castañon Guimarães e Cláudio Veiga.

\section{Júlio Castañon Guimarães, André Dick e Cláudio Veiga: sinais de outro tempo}

Em 1995, Júlio Castañon Guimarães publica uma pequena antologia dedicada exclusivamente a dois poemas de Mallarmé - Brinde Fúnebre e prosa. Ao comentar esse seu trabalho tradutório, Guimarães afirma:

Dentre as inumeráveis observações que se poderiam fazer sobre a tradução dos dois poemas, exponho aqui apenas algumas poucas que me parecem indispensáveis. Vale ressaltar, no tocante a ambos os poemas, a importância decisiva, para o trabalho deste tradutor, da releitura insistente das traduções mestras de poemas de Mallarmé realizadas por Haroldo de Campos, Augusto de Campos, Décio Pignatari e José Lino

Guimarães assume explicitamente, nesse primeiro momento, um papel de discípulo diante das "traduções mestras" de seus predecessores. Entretanto, nesse mesmo trabalho, Guimarães promove alguns ajustes e complementos importantes aos trabalhos anteriores ao seu; ainda mais afinados na segunda edição que fez de sua antologia ${ }^{44}$. A importância do trabalho de Guimarães se deve, primeiramente, ao fato de traduzir o até então inédito "Toast Funèbre" (traduzido por "Brinde Fúnebre”). Se sua escolha baseia-se em critérios que se aproximam dos de seus mestres, uma vez que visam trazer para o leitor o Mallarmé mais hermético e radical, ele o faz mobilizando uma bibliografia que recoloca algumas questões levantas por Mário Faustino. Como descreve o próprio tradutor:

Revista Letras,

43 GUIMARÃES, J. C. Brinde Fúnebre e prosa, p. 37.

44 Trata-se da versão ampliada do livro, publicada em 2007, com o título Brinde Fúnebre e outros poemas. A partir de agora, utilizaremos as citações dessa segunda edição. Em relação a esta, esclarece Guimarães (2007, p. 85): "as anotações acima, numa redação diferente, acompanhavam o volume Brinde Fúnebre e prosa". Note-se que, dentre as mudanças feitas na redação, está a retirada do parágrafo citado acima, substituído por uma nota na qual afirma: "para o trabalho de tradução aqui realizado foi importante a leitura das traduções de Mallarmé realizadas por Haroldo de Campos, Augusto de Campos, Décio Pignatari e José Lino Grünewald”.

Curitiba, UFPR, 
Émilie Noulet observa que até Hérodiade de certo modo todos os poemas de Mallarmé são claros, mas que "a partir de 'Toast Funebre' todos os poemas são perfeitamente obscuros, e exigem, se se quer entendê-los ou apenas apreciá-los, uma paciente decifração. Ele inaugura o novo sistema de Mallarmé” ${ }^{35}$.

Esse fato desloca para 1873 a terceira fase de Mallarmé, antecipando-a em mais de dez anos, se a compararmos à periodização proposta por Faustino. Guimarães percebe uma lacuna e se dá ao trabalho de preenchê-la. Sua atualização torna-se ainda mais relevante na segunda edição, sobretudo devido à inclusão do texto inacabado Épouser la notion. Diferentemente de Grünewald, que escreveu mini-ensaios de poucos parágrafos sobre os textos que traduziu, estamos diante de uma publicação que problematiza em profundidade seu objeto. No estudo de Épouser la notion, Guimarães começa refletindo sobre a natureza do próprio texto, sobre suas diferentes edições, sobre o tamanho das folhas no manuscrito, sobre sua materialidade e suas rasuras para chegar a um fato relevante, que tem modificado a recepção de Mallarmé na última década - a nova edição de sua obra completa lançada em 1998 pela Pléiade, organizada e anotada por Bertrand Marchal. Esse complexo que envolve o texto leva Guimarães a afirmar que:

No entanto, talvez mais importante do que a insistência nesses detalhes, seja a compreensão de que o manuscrito Épouser la notion tem sobretudo de ser encarado a partir de uma noção de texto só possível justamente a partir de Mallarmé, uma noção segundo a qual esse texto é inacabado, ou melhor, está sempre em andamento, não apenas porque seu manuscrito não foi levado a termo, mas também porque dele fazem parte todas as questões levantadas por seus estudiosos ${ }^{46}$.

A passagem operada por Júlio Castañon Guimarães, de sua primeira antologia, Brinde Fúnebre e prosa (1995), para a segunda, Brinde Fúnebre e outros poemas (2007), é, pois, muito mais do que a ampliação de um corpus. Trata-se de uma mudança de postura diante do objeto e de sua historicidade. Se, na primeira publicação, estamos diante de um discípulo que se pauta por "traduções mestras", na segunda verifica-se o interesse em expor a existência de um amplo contexto que determina as recepções de uma obra, da qual fazem parte "todas as questões levantadas por seus estudiosos”. Está em jogo aí não a apropriação de uma obra para determinar um campo literário, como fez a geração anterior, mas, sim, a articulação por meio de linhas de força que a atravessam; as traduções anteriores deixam de ser "traduções mestras" e passam a ser "importantes leituras" para a elaboração de mais uma camada interpretativa, sempre em andamento.

45 GUIMARÃES, J. C. 2007, op. cit., p. 64.

46 GUIMARÃES, J. C. 2007, op. cit., p.103. 
Faleiros, A.

Os tempos

de Mallarmé

nas antologias

brasileiras de poesia traduzida
Revista Letras,

Curitiba, UFPR, n. 95 143-163, jan./jun. 2017. ISSN 2236-0999 (versão eletrônica)
Uma segunda antologia dedicada exclusivamente à poesia de Mallarmé publicada neste século é Poesias de Mallarmé, publicada em 2011 por André Dick. Como Júlio Castañon Guimarães, Dick também estabelece uma relação, até certo ponto, de continuidade em relação aos trabalhos de Mário Faustino, Augusto de Campos e José Lino Grünewald. Com efeito, treze dos vinte e quatro poemas que traduz já haviam sido traduzidos por Augusto de Campos, aos quais somam-se outros dois traduzidos por Grünewald e um terceiro traduzido por Guimarães ${ }^{47}$. Situada na esfera da retradução, a antologia de André Dick conta com alentada introdução em que, após criticar a leitura estruturalista de Hugo Friedrich, mobiliza uma série de estudiosos da obra de Mallarmé para colocar em evidência alguns grandes temas que identifica como importantes, dentre os quais "a questão da verdade", "o livro" e a "melancolia". Esse último tema, por exemplo, leva Dick a, partindo de Starobinski, estabelecer relações entre fragmentos do "Tombeau pour Anatole" com poemas escritos pelo jovem Mallarmé, como "Apparition", "Tristesse d'été", "Las de l'amer repos", "Renouveau", "Les fenêtres" e "Le Pitre Châtié", os quatro últimos traduzidos pela primeira vez no Brasil na antologia de Dick. Essa aproximação tem o intuito de, sem confundi-los, estabelecer relações entre o sujeito do poema e o sujeito biográfico, em claro descolamento de leituras mais formalistas. Tal escolha não impede Dick de retomar as reflexões dos tradutores anteriores, mobilizando assim boa parte da bibliografia brasileira sobre Mallarmé. Esse distanciamento das questões formais se reflete também na ausência de um paratexto em que se comenta seu projeto tradutório. Nesse sentido, trata-se da primeira antologia dedicada exclusivamente a Mallarmé em que o tradutor-antologista não reflete e não parece atento a problemas de tradução $0^{48}$, deixando claro que seu maior interesse é colocar em evidência alguns temas, articulando-os com a dimensão biográfica do poeta ${ }^{49}$, adotando assim nova perspectiva em relação à obra de Mallarmé.

A organização da antologia de Cláudio Veiga também produz, a seu modo, outro ponto de vista sobre a poesia francesa e, nesse sentido, situa a obra de Mallarmé em outros termos. Antes é necessário lembrar que, nas primeiras antologias brasileiras envolvendo a poesia francesa, a escolha de textos correspondia a uma afinidade estética com poetas mais ou menos contemporâneos, sobretudo românticos, parnasianos e simbolistas. Esse modo de apresentar e pensar a circulação da poesia francesa no Brasil se refletiu também na Antologia de poetas franceses do séc. $X V$ ao séc. $X X$, organizada por Raimundo Magalhães Junior, em que: os poemas não eram acompanhados de seus originais; não havia comentários sobre o projeto de tradução; e tampouco referências mais históricas, éticas ou estéticas para além de breves bio-bliografias bastante escolares. É ainda

47 Todas essas antologias são citadas no ensaio introdutório de Dick.

48 O projeto tradutório de André Dick nos parece pouco claro e preciso. Cf. FALEIROS, A. Três Mallarmés: traduções brasileiras. Aletria, v. 22, 2012, p.29-30.

49 Dick inclui em seu livro um posfácio de oito páginas intitulado "Lances biográficos de Mallarmé”, algo relegado a um segundo plano nas antologias anteriores. 
importante lembrar que Guilherme de Almeida introduziu outra concepção de tradução e outro olhar sobre a poesia francesa. Seguindo os passos de Lanson, começou sua antologia com Villon, à época considerado precursor da lírica moderna francesa, chegando ao surrealismo, representado em sua antologia por Éluard, reconfigurando o campo a partir de certa visão de modernidade. Em um breve prefácio, mesmo se Guilherme de Almeida chega a se perguntar o que é traduzirir ${ }^{50}$, ele não se preocupa em historicizar sua escolha. Para ele, Poetas de França "não é uma antologia. A escolha é ligeira e livre: frívola se se quiser. Mas sincera. Sem preconceitos de escola." ${ }^{\circ 1}$.

Cláudio Veiga, diferentemente de seus predecessores, cerca sua Antologia da poesia francesa (do século IX ao século $X X$ ) de um conjunto considerável de paratextos. Primeiramente, abre o volume com um "Panorama da poesia francesa", no qual se propõe a cobrir mil anos de poesia, remontando à "Cantilena de Santa Eulália”. A história da poesia francesa que se coloca aí é outra e começa com aquele que seria "o primeiro texto literário em língua francesa" ${ }^{52}$, deslocando consideravelmente no tempo sua origem. Na introdução, Veiga também se refere à canção de gesta e, mesmo que não apresente nenhum trecho de canção, ressalta a importância histórica da Chanson de Roland. Outro deslocamento importante que Veiga produz é a inclusão de Charles d'Orléans entre os primeiros poetas franceses. Seu panorama segue avançando no tempo e, sem retomar a ideia de "correntes e vertentes", abarca distintas estéticas que atravessaram os séculos, num grande esforço de síntese. Nesse conjunto, Mallarmé comparece com cinco poemas, todos já traduzidos por Augusto de Campos; o que ilustra bem a importância do trabalho da geração anterior.

No final do volume de Veiga, há dois outros apêndices. O primeiro é histórico, sobre "A tradução de poesia francesa no Brasil", que serve de base para este nosso estudo e no qual mapeia as primeiras antologias de poesia francesa no Brasil. No segundo, intitulado "Problemas de tradução", Veiga trata de questões de métrica, de rima, amparando-se em conceitos da gramática contrastiva como "transposição" e "modulação", evidenciando sua preocupação em explicitar os impasses em jogo na tradução poética a partir de estudos linguísticos.

Assim como Guimarães, no que concerne Mallarmé, Veiga se utiliza de trabalhos anteriores e de uma concepção que coloca em destaque a fase mais hermética e experimental da poesia de Mallarmé. Veiga, a seu modo, também incorpora outra concepção de crítica e de antologização, na qual os paratextos se tornam espaço de estudo e de elaboração de um complexo de cunho mais acadêmico. Este é outro ponto importante: tanto Guimarães quanto Veiga são

50 Guilherme de Almeida declara na nota: "Ora, traduzir, nesse caso, seria antes 'reproduzir'. 'Reproduzir' no sentido autêntico, primitivo do termo: 're'-produzir, quer dizer, produzir de novo, ou seja, sentir, pensar e dizer como o autor e com o autor".

51 Op. cit. p.17.

52 VEIGA, C. Antologia da poesia francesa (do século IX ao século XX). São Paulo: Record, 1999. p. 23. 
Faleiros, A.

Os tempos

de Mallarmé

nas antologias

brasileiras de poesia traduzida sobretudo professores e pesquisadores universitários. Seus trabalhos diferem assim daqueles das gerações anteriores, para quem Mallarmé era uma referência estética; o deslocamento que produzem se deve também a essa posição que ocupam no campo, e que não se confunde mais com a do poeta.

\section{As voltas que o tempo dá}

Como foi possível constatar, há nos trabalhos de Veiga e de Guimarães certa continuidade no recorte feito da obra de Mallarmé em relação à geração anterior. Paralelamente, ocorreu outro fenômeno envolvendo a presença de Mallarmé nas antologias, isto é, surgiram publicações que representam, de certo modo, uma volta ao passado.

Na primeira delas, em 1988, Dante Milano publica Poemas traduzidos de Baudelaire e Mallarmé, em que aproxima Mallarmé de certo simbolismo ao incluir ali "Salut" (traduzido por "Saudação") e a Cena II de "Hérodiade". Na segunda antologia, publicada em 1998, José Jeronymo Rivera traduz os poemas de juventude "Apparition" e "Soupir". Dois anos depois, em sua Poesia francesa: pequena antologia bilingue, Paulo Hecker Filho insere, em sua antologia pessoal intitulada Só poema bom, uma tradução de "Brisa Marinha". Na quarta dessas publicações, intitulada Pequena antologia de poemas franceses, de 2002, Renata Cordeiro inclui sua tradução do poema "Apparition". Como se pode perceber, trata-se de um Mallarmé que não se distingue daquele traduzido Batista Cepellos, Alphonsus de Guimarães e Guilherme de Almeida. Em termos de organização interna, contudo, os trabalhos de Dante Milano e de José Jeronymo Rivera aproximam-se do Poetas de França de Guilherme de Almeida, uma vez que optam por edições bilíngues acompanhadas de breves introduções, mas sem grandes paratextos, enquanto, em Paulo Hecker Filho e de Renata Cordeiro, a edição remonta à estrutura das antologias de Álvaro Reis, Olegário Marianno e Magalhães Júnior, ou seja, edições monolíngues compostas de escolhas bastante pessoais.

Enfim, percebe-se, neste início de século, renovado interesse pela poesia francesa e pela poesia de Mallarmé. Nota-se também que, ainda que haja uma nova maneira, mais acadêmica, de se editar, criticar e traduzir Mallarmé, esse modo convive hoje com outros anteriormente constituídos, mas que seguem inspirando novos trabalhos. Essa coexistência aponta para o fato de que o surgimento dessas novas práticas na edição e na crítica não necessariamente levam ao desaparecimento das anteriores, cabendo a cada uma delas funções distintas no sistema literário. Funções essas que vão desde o desejo de delimitar o campo da própria poesia brasileira até estudos de cunho mais acadêmico, passando por trabalhos mais pessoais e pontuais. Nesse contexto, pensar o tempo das traduções e as formas de se antologizar Mallarmé parecer ser um instrumento profícuo para se perceber o complexo enredo que envolve a recepção de um poeta que, pelo impacto e multiplicidade de sua obra, segue abrindo espaços possíveis de reescrita e de interpretação.
Revista Letras, Curitiba, UFPR, n. 95 143-163, jan./jun. 2017. ISSN 2236-0999 (versão eletrônica) 


\section{Referências}

ALMEIDA, G. Poetas de França. 4. Ed. São Paulo: Cia Editora Nacional, 1965.

BOAVENTURA, M. E. Lendo com o leitor, In: FAUSTINO, M. Artesanatos de poesia. São Paulo: Cia das Letras, 2004. p.17-40.

BRITTO, P. H. O tradutor como antologista. In: TORRES, M-H.; FREITAS, L. F. de; COSTA, W. C. Literatura Traduzida: antologias, coletâneas e coleções. Fortaleza: Substânsia, 2016.

CAMPOS, A.; PIGNATARI, D.; CAMPOS, H. Teoria da poesia concreta: textos críticos e manifestos 1950-1960. São Paulo: Edições Invenção, 1965.

CAMPOS, A. Linguaviagem. São Paulo: Cia. das Letras, 1987. Poesia da recusa. São Paulo: Perspectiva, 2011.

CORDEIRO, R. Pequena antologia de poemas franceses. São Paulo: Landy, 2002.

COSTA, D. P. P da. "Villon retraduzido". Cadernos de Literatura em Tradução, n.13, 2012, p.37-51.

FALEIROS, Á. Três Mallarmés: traduções brasileiras. Aletria, v. 22, 2012, p.17-31.

FAUSTINO, M. Artesanatos de poesia. São Paulo: Cia das Letras, 2004.

GRÜNEWALD, J. L. Transas, traições, traduções. Salvador: Código, 1982. Poetas franceses do século XIX. Nova Fronteira: Rio de Janeiro,

1991.

GUIMARÃES, J. C. Brinde Fúnebre e prosa. 7Letras: Rio de Janeiro, 1995. . Brinde Fúnebre e outros poemas. 7Letras: Rio de Janeiro, 2007.

"Presença de Mallarmé no Brasil". In: Reescritas e Esboços. Rio de Janeiro: Topbooks, 2010.

HECKER FILHO, P. Só poema bom. Porto Alegre: Alcance, 2000.

LEFEVERE, A. Tradução, reescrita e manipulação da fama literária. Trad. Claudia Matos Seligmann. Bauru: Edusc, 2007.

MALLARMÉ, S. Brinde Fúnebre e outros poemas. Organização e Trad. Júlio Castañon Guimarães. Rio de Janeiro: 7Letras, 2007. . Igitur. Organização e Trad. José Lino Grünewald. Nova Fronteira: Rio de Janeiro, 1985. 
Faleiros, A.

Os tempos de Mallarmé nas antologias brasileiras de poesia traduzida
Mallarmé. Organização, tradução e notas de Augusto de Campos, Décio Pignatari, Décio e Haroldo de Campos. São Paulo: Perspectiva, [1974] 1991.

$$
\text { Poemas. Organização e Trad. José Lino Grünewald. Nova }
$$
Fronteira: Rio de Janeiro, 1990.

Poesias de Mallarmé. Organização e Trad. André Dick. São Paulo: Lume Editor, 2011.

MARIANNO, O. (org.). Antologia de Tradutores. Rio de Janeiro: Guanabara, 1932.

MILANO, D. Poemas traduzidos de Baudelaire e Mallarmé. Rio de Janeiro: Ed. Boca da Noite, 1988.

REIS, Á. (Org.). Musa Francesa. Salvador, 1917.

TORRES M-H., FREITAS, L. F. de; COSTA, W. C. Literatura Traduzida: antologias, coletâneas e coleções. Fortaleza: Substânsia, 2016.

VEIGA, C. V. Antologia da Poesia Francesa. Rio de Janeiro: Record, 1999.

Submetido em: 20/09/2016

Aceito em: 22/12/2016 